\title{
The McMinn Ranch Site (41CP72) in the Dry Creek Valley, Camp County, Texas
}

Timothy K. Perttula

Heritage Research Center, Stephen F. Austin State University

Follow this and additional works at: https://scholarworks.sfasu.edu/ita

Part of the American Material Culture Commons, Archaeological Anthropology Commons, Environmental Studies Commons, Other American Studies Commons, Other Arts and Humanities Commons, Other History of Art, Architecture, and Archaeology Commons, and the United States History Commons

Tell us how this article helped you.

This Article is brought to you for free and open access by the Center for Regional Heritage Research at SFA ScholarWorks. It has been accepted for inclusion in Index of Texas Archaeology: Open Access Gray Literature from the Lone Star State by an authorized editor of SFA ScholarWorks. For more information, please contact cdsscholarworks@sfasu.edu. 


\section{The McMinn Ranch Site (41CP72) in the Dry Creek Valley, Camp County, Texas Creative Commons License \\ (c) $($ i) (9)}

This work is licensed under a Creative Commons Attribution-NonCommercial 4.0 International License 


\title{
The McMinn Ranch Site (41CP72) in the Dry Creek Valley, Camp County, Texas
}

\author{
Timothy K. Perttula
}

\section{INTRODUCTION}

The McMinn Ranch site (41CP72) is a small (less than an acre) prehistoric site on an alluvial terrace along the north side of the lower reaches of Dry Creek, an important eastward-flowing tributary to Big Cypress Creek. In addition to a cluster of several Late Caddo Titus phase settlements and small cemeteries in this part of the valley (Thurmond 1990:58; Perttula 2013a; Perttula et al. 2010), there are Middle and Late Caddo settlements and a large Titus phase cemetery at the nearby Harold Williams site (41CP10) (Turner 1997; Turner and Smith 2003) as well as a large Titus phase community cemetery at the Tuck Carpenter site (41CP5) (Turner 1978, 1992). This article is a discussion of the McMinn Ranch site based on the recent analysis of an assemblage of artifacts in a surface collection gathered by Robert L. Turner, Jr. some unknown number of years ago.

\section{ARTIFACTS}

\section{Ceramic Sherds}

There are 286 ceramic sherds in the McMinn Ranch site surface collection (Table 1), including 28 vessel rim sherds. The proportions of the rims between the different wares suggest that all three wares are well represented at the site: $25 \%$ plain ware; $39 \%$ utility ware; and $36 \%$ fine ware. The plain to decorated sherd ratio for this assemblage is 1.53 .

Table 1. Ceramic sherds from the McMinn Ranch site.

\begin{tabular}{lllll}
\hline Ware & Rim & Body & Base & N \\
\hline Plain ware & 7 & 150 & 16 & 173 \\
Utility ware & 11 & 57 & - & 68 \\
Fine ware & 10 & 35 & - & 45 \\
\hline Totals & 28 & 242 & 16 & 286 \\
\hline
\end{tabular}

The McMinn Ranch ceramic sherd assemblage is from vessels almost exclusively tempered with grog or crushed sherds, regardless of the ware (Table 2). The use of bone temper ranges from 4.4-7.3\% by ware, and one red-slipped body sherd is from a shell-tempered vessel, either an undecorated portion of an Avery Engraved carinated bowl or deep bowl or a sherd from a Clement Redware vessel (see Flynn 1976). This latter vessel, regardless of the type, is likely an import from a McCurtain phase Caddo group living on the middle reaches of the Red River after ca. A.D. 1300 (e.g., Perttula et al. 2012). 
Table 2. Temper use in the ceramic wares.

\begin{tabular}{lllll}
\hline Ware & grog temper & bone temper & shell temper & $\mathrm{N}$ \\
\hline plain & $94.8 \%$ & $5.2 \%$ & - & 173 \\
utility & $92.7 \%$ & $7.3 \%$ & - & 68 \\
fine & $93.4 \%$ & $4.4 \%$ & $2.2 \%$ & 45 \\
& & & & 286 \\
\hline Totals & $94.1 \%$ & $5.6 \%$ & $0.3 \%$ & \\
\hline
\end{tabular}

Utility wares comprise $60 \%$ of the decorated sherds, and $52 \%$ of the decorated rim sherds (Table 3 ). Engraved sherds are the single most common decorative category in the decorated sherd assemblage (31\%), followed by brushed sherds (19.5\%), and sherds from incised vessels (15\%). Of the sherds with brushing - as the sole decorative method or in combination with other decorative methods - they represent $28.3 \%$ of all the decorated sherds and $47 \%$ of all the utility wares. These proportions of brushed sherds, in conjunction with the plain to decorated sherd ratio of 1.53, suggests that the McMinn Ranch site ceramic assemblage may date to the latter part of the Middle Caddo period in the Big Cypress Creek basin (Perttula 2013b:Table 8-20), and not to the Late Caddo Titus phase as suggested by Thurmond (1990). Radiocarbon or thermoluminescence dates from the assemblage are needed to evaluate the chronological possibilities.

Table 3. Decorative methods represented in the utility wares and fine wares from the McMinn Ranch site.

\begin{tabular}{llll}
\hline Ware & Rim & Body & N \\
\hline Fine Wares & & & 37 \\
Engraved & 10 & 27 & 8 \\
Red slipped & - & 8 & 45 \\
Sub-total & 10 & 35 & \\
& & & 4 \\
Utility Wares & - & 4 & 22 \\
Appliqued & 2 & 20 & 1 \\
Brushed & - & 1 & 7 \\
Brushed-appliqued & 1 & 6 & 17 \\
Brushed-incised & 2 & 15 & 2 \\
Incised & 1 & 3 & 5 \\
Incised-brushed-punctated & 2 & 1 & 9 \\
Incised-punctated & - & 6 & 68 \\
Pinched & 3 & 57 & \\
Punctated & 11 & & 113 \\
Sub-total & & 92 & \\
& 21 & & \\
\hline Totals & & & \\
\end{tabular}




\section{Fine Wares}

Almost $40 \%$ of the decorated sherds from the site are from fine ware vessels (see Table 3 ). In turn, $82 \%$ of the fine wares (carinated bowls and bottles) have engraved designs (two of these sherds also have a red slip), and the remaining fine wares are sherds from vessels decorated only with a red slip.

\section{Engraved Bottle Sherds}

Approximately 13\% $(\mathrm{n}=5)$ of the engraved sherds are from bottles with burnished and polished exterior surfaces (Figure 1a-c). One bottle neck rim has a series of horizontal engraved lines, while the body sherds have sets of curvilinear and/or opposed engraved lines that would have encircled the vessel body. Two of these body sherds - including one with a red pigment rubbed in the engraved lines (Figure 1c) - have hatched or excised pendant triangles on the curvilinear lines.

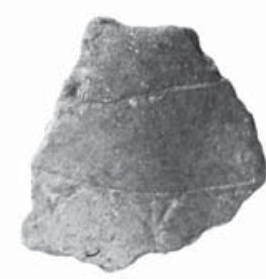

a

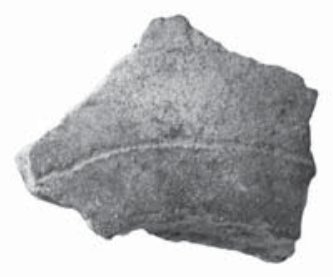

b

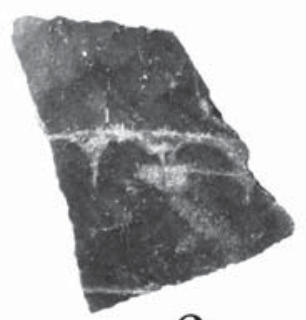

$\mathrm{C}$ $\underline{0}$

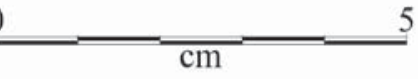

\section{Engraved Carinated Bowl Sherds}

There are 32 rim and body sherds from engraved carinated bowls, $71 \%$ of the fine wares in the decorated sherd assemblage (see Table 3 ). Two of these sherds $(6.3 \%)$ have a pigment (white or red) rubbed in the engraved lines, and two others have a red slip on one (Figure 2a) or both (Figure 2f) vessel surfaces).

Figure 1. Engraved bottle sherds.

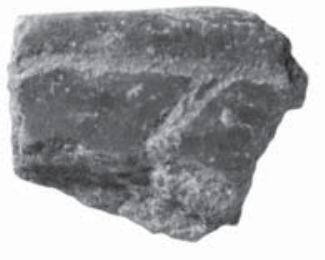

a

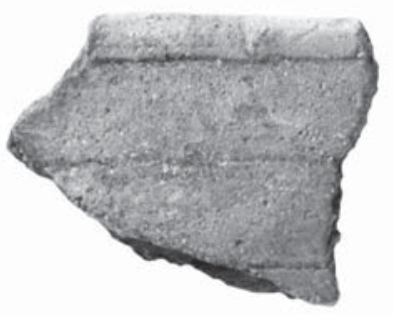

e
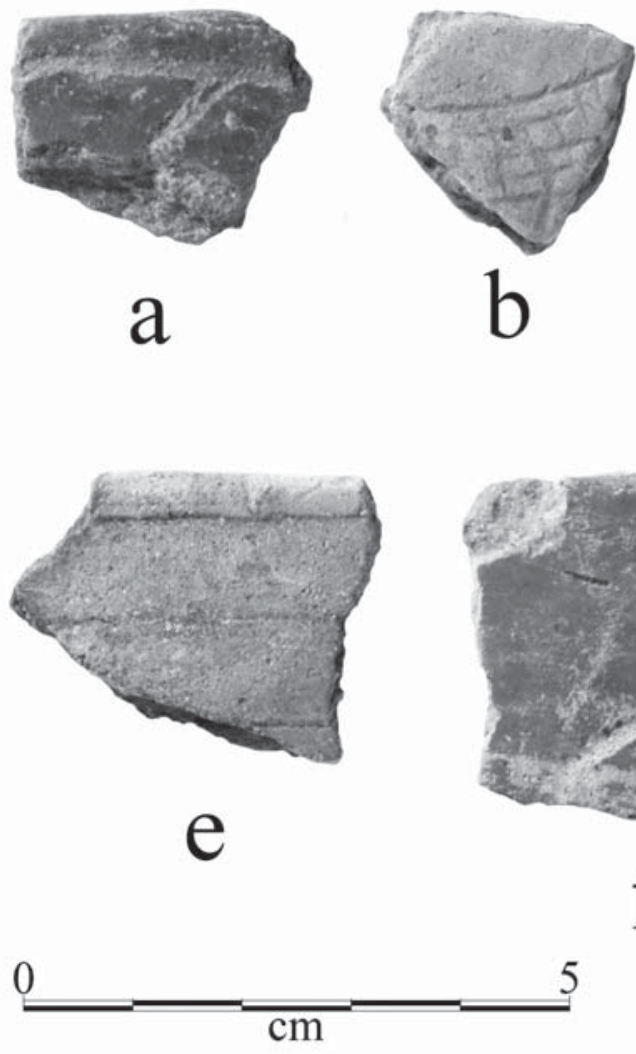

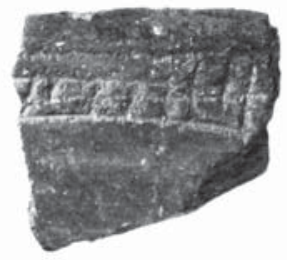

C
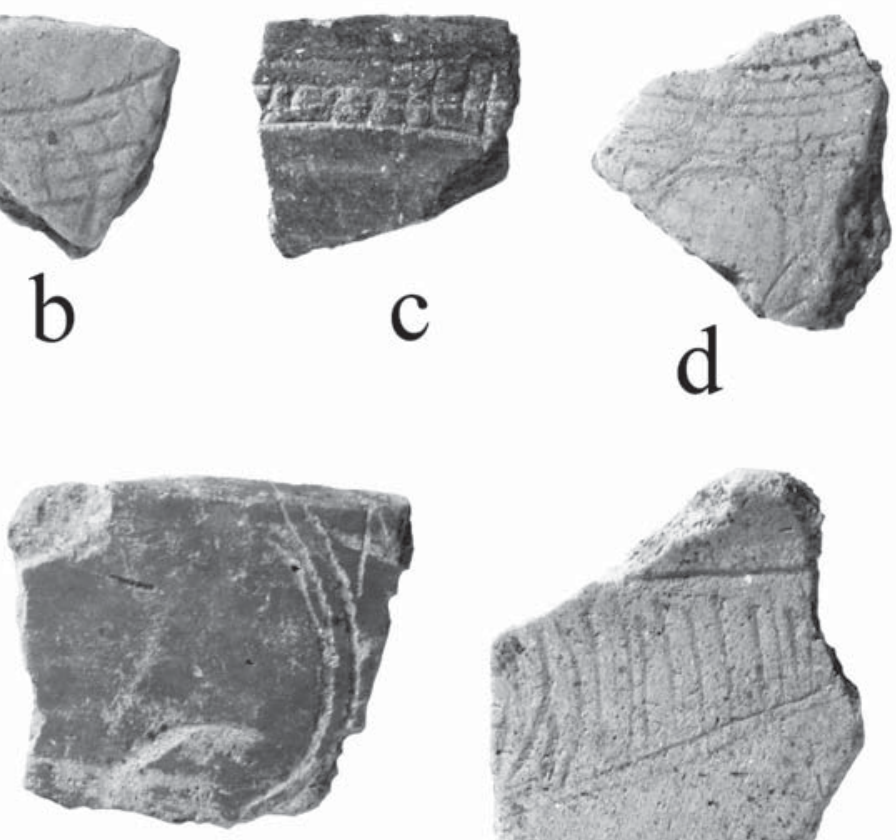

$\mathrm{f}$
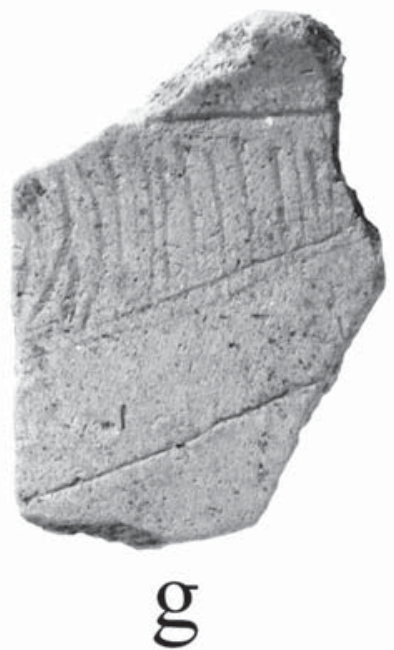

Figure 2. Engraved carinated bowl rim and body sherds: a, e, g, rim sherds; b-d, f, body sherds. 
There are several different engraved decorative elements in the carinated bowls at the McMinn Ranch site (Table 4). Most of these (i.e., $78 \%$ of the rims and $26 \%$ of the body sherds) feature one or more horizontal engraved lines on the rim (see Figure 2a, e), and a few have attached pendant triangles. Others have sets of curvilinear lines, either by themselves, or with an engraved circle (see Figure 2d), there are engraved semi-circles (see Figure 2f) and several others have diagonal engraved lines or cross-hatched engraved zones (see Figure 2b-c).

Table 4. Decorative elements on engraved carinated bowl sherds from the McMinn Ranch site.

\begin{tabular}{lccc}
\hline Decorative Element & Rim & Body & N \\
\hline Cross-hatched engraved zone & - & 2 & 2 \\
Curvilinear engraved line & - & 4 & 4 \\
Curvilinear engraved lines and circle element & - & 1 & 1 \\
Diagonal engraved lines & - & 2 & 2 \\
Hatched zone & - & 1 & 1 \\
Horizontal engraved lines & & 2 & 3 \\
Horizontal engraved line under vessel lip & 1 & 2 \\
Horizontal engraved line and hatched pendant triangle & 3 & - & 2 \\
Horizontal and diagonal engraved lines & - & 1 & 3 \\
Horizontal and diagonal engraved lines and hatched pendant triangle & - & 1 & 1 \\
Parallel engraved lines & 3 & 5 & 5 \\
Scroll, slanted and hatched scroll fill zone & - & 1 \\
Semi-circle engraved element & 1 & - & 1 \\
Vertical engraved lines & - & 1 & 1 \\
Vertical engraved lines and associated excised area & - & - & 1 \\
\hline
\end{tabular}

Only one engraved sherd in the McMinn Ranch site fine ware assemblage has a scroll motif (see Figure $2 \mathrm{~g}$ ). This rim has a slanting scroll line and an upper scroll fill zone with curvilinear to straight hatched lines.

\section{Red-Slipped Sherds}

Seven of the eight red-slipped body sherds have a slip on both interior and exterior surfaces, indicating they are from bowls, carinated bowls, or compound bowls; this includes the one shell-tempered red-slipped sherd. The other body sherd has a red slip only on the exterior surface, but it does not appear to be from a bottle because it does not have a roughened interior surface as most bottle sherds do.

\section{Utility Wares}

As mentioned above, sherds with brushing on the rim and/or the vessel body represent the most prevalent kind of utility ware vessel at the McMinn Ranch site. Sherds with brushing comprise $36 \%$ of the utility 
ware rims and $30 \%$ of the utility ware body sherds (see Table 3). Other utility ware sherds have appliqued, punctated, and pinched decorative elements.

The appliqued sherds, all grog-tempered, are body sherds. One has an appliqued node, while the other three have appliqued ridge elements; two of these have straight ridges and the other has a curvilinear appliqued ridge.

The brushed sherds are from vessels that are horizontally brushed on the rim ( $n=2$, Figure $3 \mathrm{c})$; these may be from Bullard Brushed or Pease Brushed-Incised jars. The body sherds have parallel brushing marks $(n=18$, Figure 3b, d-e), parallel-opposed brushing $(n=1$, Figure $3 f)$, or vertical brushing $(n=1)$.

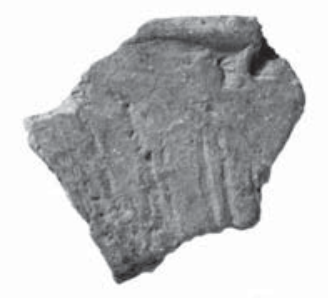

a

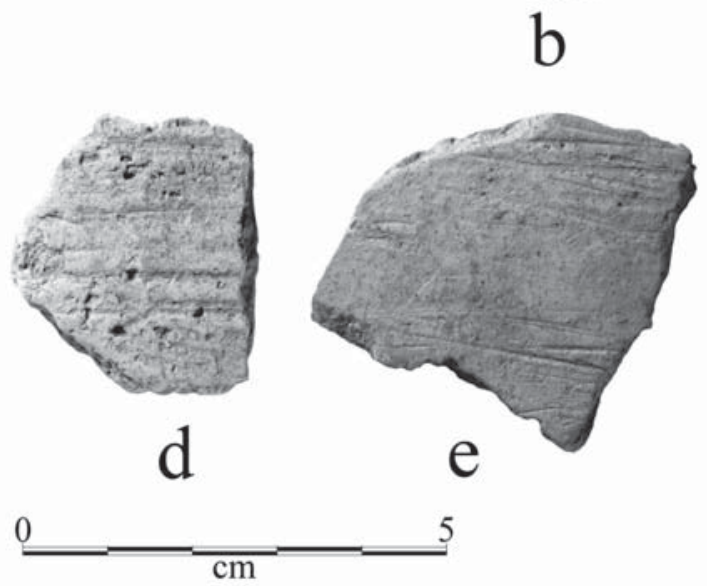

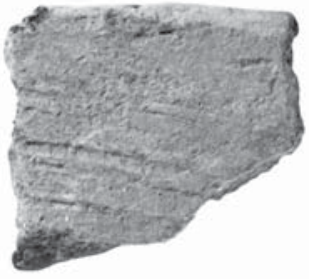

C

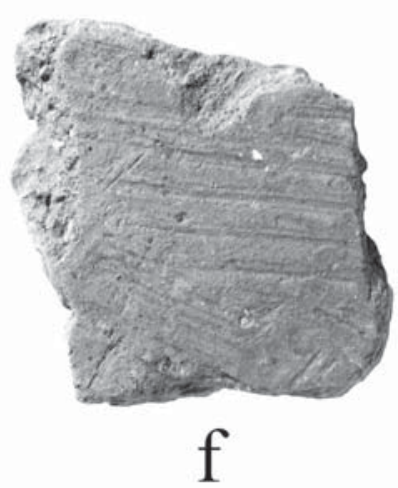

Figure 3. Brushed and brushed-incised sherds: a, brushed-incised rim; b-f, brushed sherds.

\section{Brushed-Appliqued}

The one brushed-appliqued body sherd in the McMinn Ranch collection may be from a Pease BrushedIncised jar. The sherd has a straight appliqued fillet and parallel brushing marks on either side of the fillet.

\section{Brushed-Incised}

The seven sherds with brushed-incised decorative elements include a rim and six body sherds. The rim has diagonal brushed-incised marks and lines (see Figure 3a). Five of the body sherds have parallel brushedincised lines and the other is parallel brushed with parallel incised lines drawn over the brushing marks.

\section{Incised}

One of the incised rims has a set of diagonal lines, while the other, perhaps from a Maydelle Incised vessel (see Suhm and Jelks 1962:Plate 52c) has cross-hatched incised lines (Figure 4a). Body sherds have parallel incised lines ( $n=11$, Figure $4 d-e)$, parallel and opposed lines ( $n=1$, Figure $4 c)$, cross-hatched lines $(n=1)$, and cross-hatched and opposed lines $(n=1$, Figure $4 b)$. 


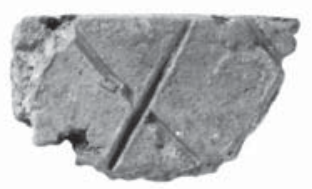

a
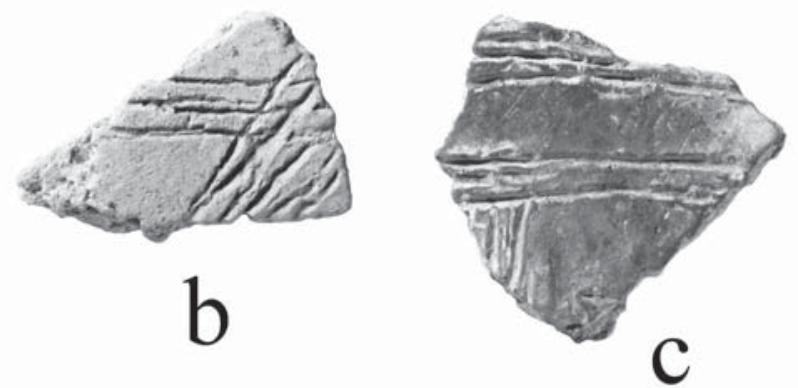

0 5
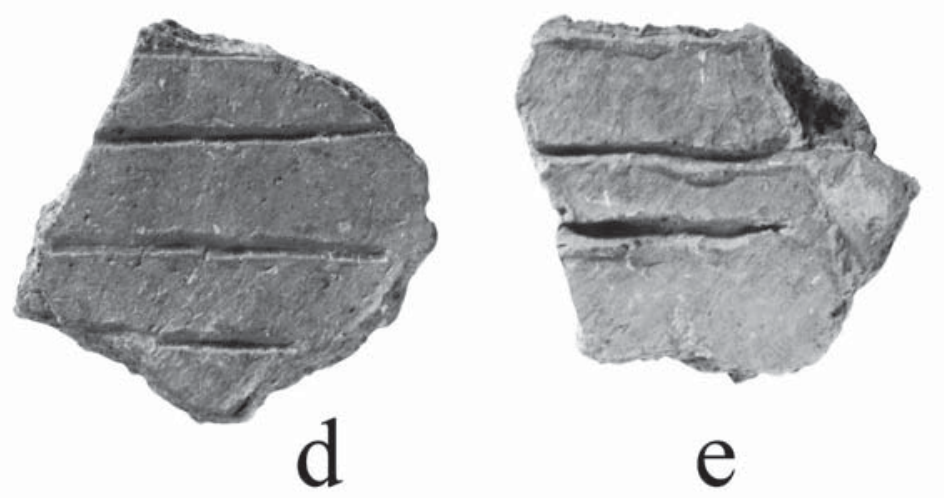

e

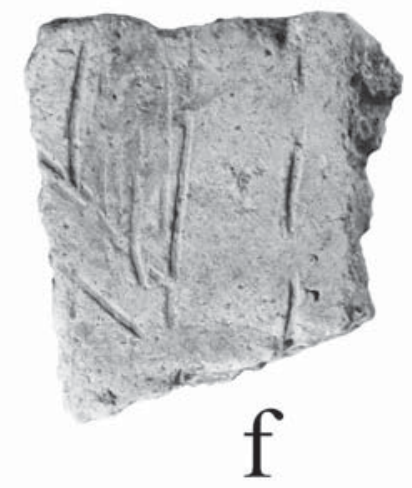

Figure 4. Incised rim and body sherds and incised-punctated body sherd: a-e, incised; f, incised-punctated.

\section{Pinched}

There is one body sherd in the collection with a pinched decoration. It has closely-spaced rows of pinching (Figure 5e), perhaps from a Killough Pinched jar (see Suhm and Jelks 1962:Plate 46f).

\section{Punctated}

The punctated sherds have rows of either tool ( $n=7$, see Figure 5b-c and Figure 6c, below), fingernail $(n=1$, see Figure 5a), or large circular ( $n=1$, see Figure $5 d$ ) punctations. The punctations are in rows, beginning under the lip, on the rim and/or the vessel body.

\section{Incised-Punctated}

The incised-punctated sherds represent $7.3 \%$ of the utility wares in the McMinn Ranch assemblage (see Table 3). One rim has vertical and curvilinear incised lines adjacent to a zone of circular tool punctations (Figure 6a), while another, likely from a Maydelle Incised jar, has a set of diagonal incised lines forming triangles filled with tool punctations.

The three incised-punctated body sherds have different decorative elements. One has a row of tool punctations adjacent to a single straight incised line. The second (see Figure 4f) has an incised triangle filled with incised lines, with a diagonal row of linear punctations likely separating sets of incised triangles. The last incised-punctated body sherd (or more precisely, a lower rim-body sherd) in the collection has a horizontal row of punctations at the rim-body juncture, with a single horizontal incised line above that on the rim, and opposed sets of diagonal incised lines. 


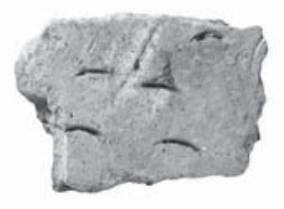

a

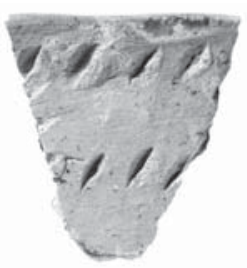

b

$\underline{0}$

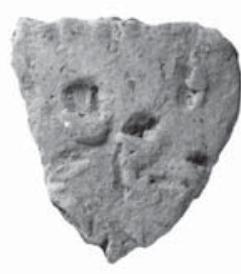

c

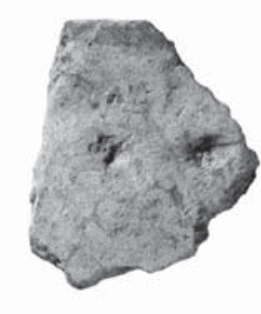

d
5

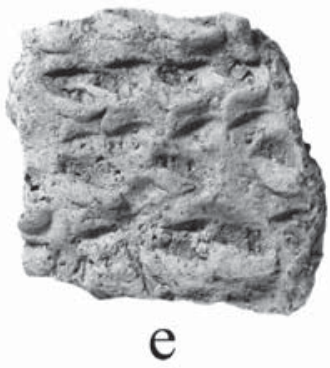

Figure 5. Punctated and pinched rim and body sherds: $\mathrm{a}-\mathrm{d}$, punctated; e, pinched.
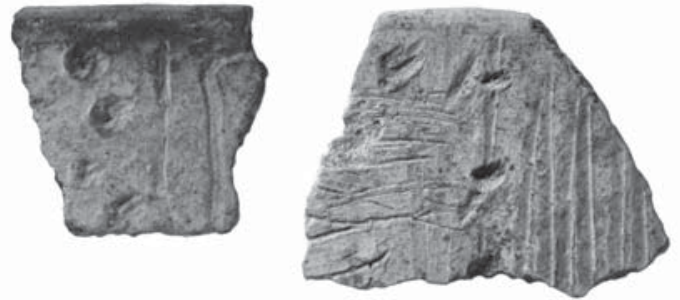

a

0
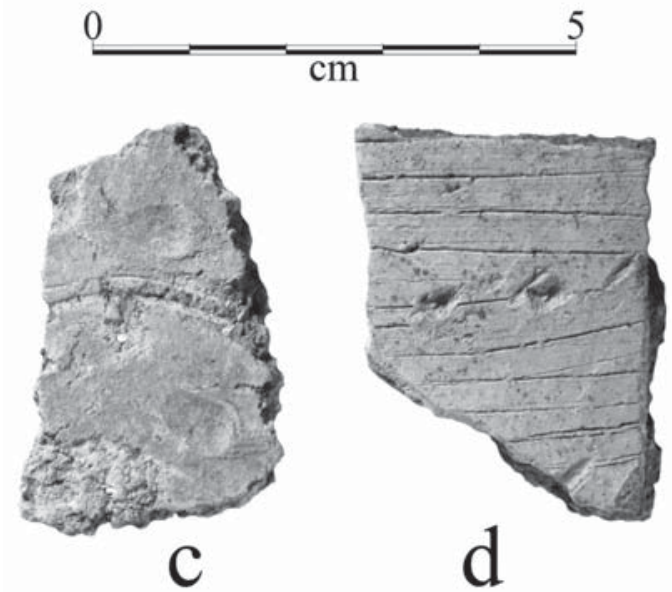

Figure 6. Incised-punctated, punctated, and incised-brushed-punctated sherds: a, incised-punctated rim sherd; b, d, incisedbrushed-punctated sherds; c, tool punctated body sherd.

\section{Incised-Punctated-Brushed}

Both incised-punctated-brushed sherds are from grog-tempered vessels. The rim has both vertical incised lines and a row of vertical tool punctates, as well as a row of tool punctates under the vessel lip (see Figure 6b). Opposite the set of vertical incised lines is an area with horizontal brushing. The one body sherd, probably from a Pease Brushed-Incised vessel, has parallel brushed-incised lines, with a row of tool punctations pushed through the brushed-incised lines (see Figure 6d).

\section{Fired Clay Pieces}

The collection also has three thick, large, and conjoinable pieces of fired clay. The pieces are flat and disk-shaped (ca. $140 \times 80$ $\mathrm{mm}$ in length an width), a hefty $30 \mathrm{~mm}$ in thickness, with unsmoothed and unprepared surfaces. The pieces have both an oxidized and reduced core, although the surface is primarily an oxidized color. The function of these clay pieces is unknown, although it is possible that they represent a griddle or clay platform to rest flat-based ceramic vessels on when they were to be placed in a cooking fire.

\section{Lithic Artifacts}

There are 13 chipped stone tools in the McMinn Ranch surface collection. This includes three arrowpoints: a Perdiz point made from a gray chert (Figure 7a), a unifacially flaked Maud arrow point made from a light gray chert, and a light gray chert arrow point medial fragment. There are also three small, thin, and narrow Gary dart points of Woodland period age (Figure 7b-d), two made from novaculite and the third from a heat-treated quartzite.

There is also a lightly heat-treated quartzite bifacial knive (see Figure $7 \mathrm{~g}$ ) and two biface fragments: one of gray chert and the other of white chert (see Figure 7e). The remaining tools are a heat-treated quartzite side scraper (see Figure 7f) and a gray novaculite scraper fragment, as well as a grayish-brown unilateral flake tool and a grayish-white drill. Almost $77 \%$ of the 


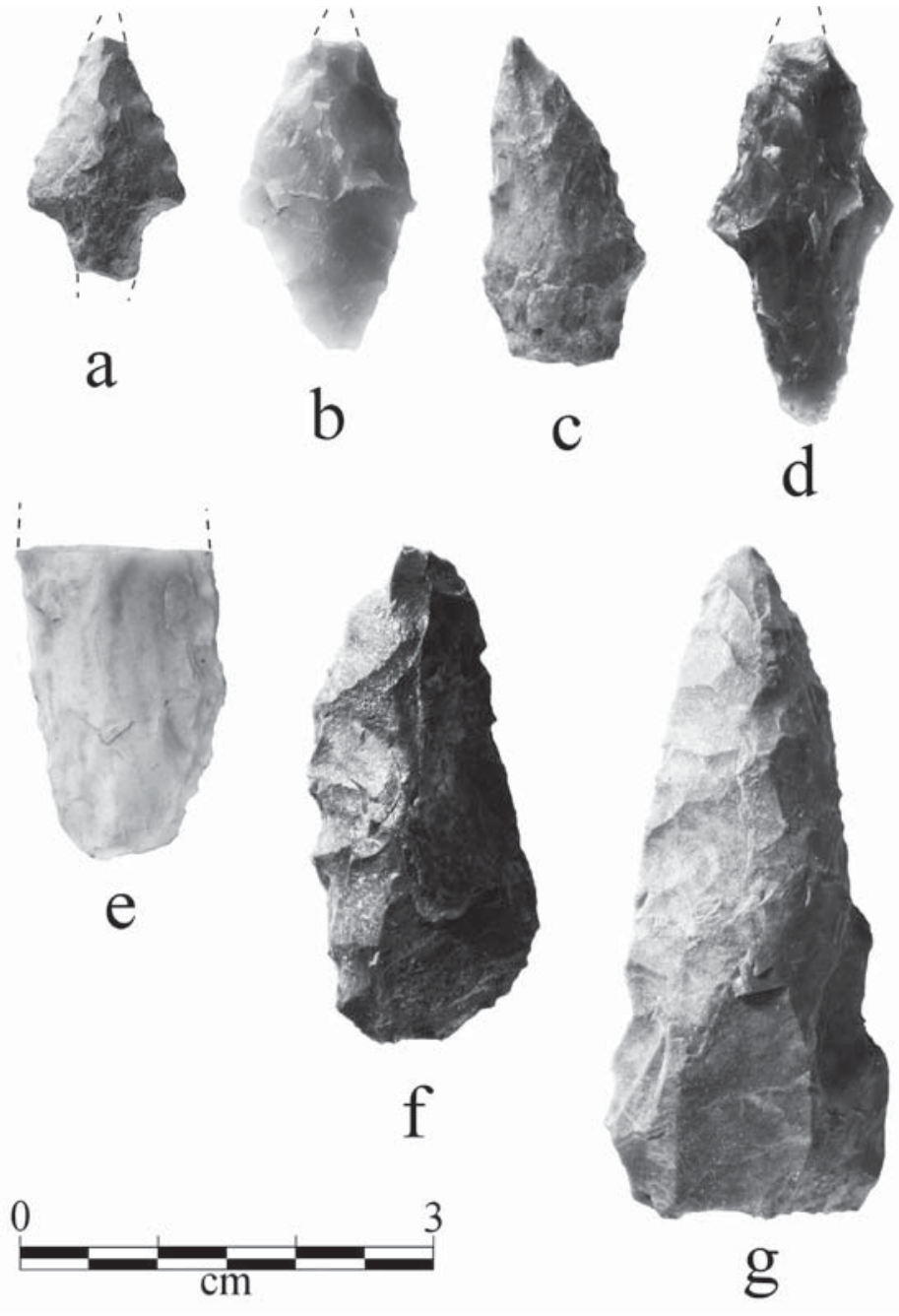

Figure 7. Chipped stone tools from the McMinn Ranch site: a, Perdiz arrow point; b-d, Gary points; e, biface fragment; $\mathrm{f}$, side scraper; g, bifacial knive. chipped stone tools in the McMinn Ranch collection are made from non-local lithic raw materials, primarily from Ouachita Mountains sources.

There are 13 pieces of lithic debris in the lithic artifact assemblage. One appears to be a resharpening flake from a celt made from a grayish-green metamorphic rock with whitish-blue inclusions; this raw material likely has a source in the Ouachita Mountains, well to the north of the site. Other non-local raw materials from Ouachita Mountains sources represented in the lithic debris include Big Fork chert $(n=3)$, orange novaculite $(n=1)$, grayish-brown chert $(n=1)$, dark gray chert $(n=1)$, and gray chert $(n=1)$. The one local lithic raw material in the lithic debris is quartzite $(n=5)$.

In addition to the chipped stone tools, the collection also has a quartzite cobble with edge abrading and pecking. The tool may have been used as a hammerstone

\section{Animal Bones and Mussel Shell}

In the collection are 10 pieces of animal bone and a freshwater mussel shell fragment. Half the animal bone is burned, and the bone appears to be from both large and small mammals.

\section{SUMMARY AND CONCLUSIONS}

The McMinn Ranch site is a small ancestral Caddo settlement in the Dry Creek valley of the Big Cypress Creek basin in East Texas. It probably has preserved midden deposits, based on the recovery of animal bones and mussel shell fragments in the surface collection. Most of the artifacts recovered by Robert L. Turner, Jr. in his surface collection are plain and decorated ceramic sherds, along with a small assortment of chipped stone tools that suggest the site was first occupied during the latter part of the Woodland period (ca. A.D. 200-700). The principal occupation, however, was by ancestral Caddo peoples who made certain kinds of grog-tempered plain wares, utility wares, and fine ware vessels.

The kinds and proportions of decorated sherds recovered at the McMinn Ranch help to situate the Caddo occupation temporally, as do the engraved fine wares. None of the engraved fine wares can be confidently identified as Ripley Engraved, a post-A.D. 1430 fine ware in the basin. Furthermore, reported ceramic assemblages in the Big Cypress Creek basin (see Perttula 2013b:Table 8-20) indicate that through time, brushed pottery becomes an important decorative component in the utility wares, the proportion of brushed 
pottery appears to increase through time, and greater proportions of sherds in different assemblages tend to be decorated versus those that are plain: this suggests that through time more Caddo vessels become decorated on both the rim and the body.

Pre-A.D. 1200 components in the Big Cypress Creek basin have decorated ceramics where brushed surfaces are virtually absent (see Perttula 2013b:Table 8-20) and plain/decorated (P/DR) sherd ratios range from 2.59-5.96, with a mean of 4.28. After ca. A.D. 1200, and perhaps not until after ca. A.D. 1250 or a bit later (see discussion in Perttula and Ellis 2012:201-208 and Table 8-24), brushing of vessel bodies and rims becomes one of the more dominant decorative techniques, occurring in frequencies between 10-43\% in analyzed assemblages. P/DR ratios on Middle Caddo sites in the Big Cypress Creek basin range from 0.98-2.61, with a mean of 1.89. Continuing with the trend in the manufacture and use of brushed pottery as an important part of Caddo ceramic assemblages, after ca. A.D. 1400, in Late Caddo assemblages in this part of the Big Cypress Creek basin brushed pottery comprises between 41-76\% of the decorated sherds (see Perttula 2013b:Table 8-20), with an east to west spatial trend in the frequency of brushing. P/DR values range from 0.57-1.48, with a mean P/DR value for these sites and components of 0.95. Given the location of the McMinn Ranch site in the western part of the Big Cypress Creek basin, it has P/DR values and relative proportions of brushed sherds that are consistent with a local Middle Caddo period (ca. A.D. 1200-1430) ceramic assemblage.

\section{ACKNOWLEDGMENTS}

Lance Trask prepared the figures for this article.

\section{REFERENCES CITED}

Flynn, P.

1976 A Study of Red-Filmed Pottery from the Clement Site (Mc-8), McCurtain County, Oklahoma. Bulletin of the Oklahoma Anthropological Society 25:127-134.

Perttula, T. K.

2013a The Linebarger Site on Dry Creek, Camp County, Texas. Journal of Northeast Texas Archaeology 40:31-34.

2013b Kitchen Branch Site Ceramic Analysis. In Archeological Investigations at the Kitchen Branch (41CP220), Horton (41CP20), and Keering (41CP21) Sites in the Big Cypress Creek Basin, Camp County, Texas, by T. K. Perttula, Ch. 8. AmaTerra Environmental, Inc., Austin.

Perttula, T. K. and L. W. Ellis

2012 The Hickory Hill Site (41CP408): Archeological Investigations at a Middle Caddo Site in the Little Cypress Creek Basin in East Texas. Document No. 120055. Atkins Group, Austin.

Perttula, T. K., M. B. Trubitt, and J. S. Girard

2012 The Use of Shell-Tempered Pottery in the Caddo Area of the Southeastern United States. Southeastern Archaeology 30(2):242-267.

Perttula, T. K., M. Walters, and B. Nelson

2010 Caddo Pottery Vessels and Pipes from Sites in the Big Cypress, Sulphur, Neches-Angelina, and Middle Sabine River Basins in the Turner and Johns Collections, Camp, Cass, Cherokee, Harrison, Morris, Titus, and Upshur Counties, Texas and Sabine Parish, Louisiana. Special Publication No. 10. Friends of Northeast Texas Archaeology, Pittsburg and Austin.

Thurmond, J. P.

1990 Archeology of the Cypress Creek Drainage Basin, Northeastern Texas and Northwestern Louisiana. Studies in Archeology 5. Texas Archeological Research Laboratory, The University of Texas at Austin. 
Turner, R. L.

1978 The Tuck Carpenter Site and Its Relations to Other Sites within the Titus Focus. Bulletin of the Texas Archeological Society 49:1-110.

1992 Prehistoric Mortuary Remains at the Tuck Carpenter Site, Camp County, Texas. Studies in Archeology No. 10. Texas Archeological Research Laboratory, The University of Texas at Austin.

1997 Observations on Four Probable Middle Caddo Cemeteries in Camp and Upshur Counties. Journal of Northeast Texas Archaeology 10:12-35.

Turner, R. L. and J. E. Smith II

2003 The Harold Williams Site (41CP10) and the Texas Archeological Society Field School of 1967. Bulletin of the Texas Archeological Society 73:1-68. 